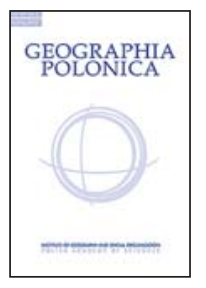

\title{
BIOCLIMATIC CONDITIONS AND THERMAL SEASONS OF THE YEAR IN SZCZECIN
}

\section{Agnieszka Mąkosza (D)}

Department of Environmental Management West Pomeranian University of Technology in Szczecin Papieża Pawła VI 3A, 71-459 Szczecin: Poland e-mail: agnieszka.makosza@zut.edu.pl

\begin{abstract}
Climate change is an empirical fact evidenced by subsequent IPCC reports. The observed climate change is also manifested in the altered date of occurrence and duration of the seasons in a year. Variability of thermal conditions due to climate warming will have its toll on the bioclimatic conditions. The assessment of bioclimatic conditions was conducted with the use of Universal Thermal Climate Index (UTCI). The present elaboration is based on hourly values of the following meteorological elements: air temperature, relative air humidity, wind speed and cloud cover. The meteorological data were obtained from the Institute of Meteorology and Water Management - National Research Institute (IMGW-PIB) in Szczecin and cover the period 2000-2019. Variability of bioclimatic conditions is considered per periods corresponding to thermal seasons of the year as identified by the Gumiński (1948) method on the basis of monthly air temperature values. The analysed UTCI values with respect to thermal seasons indicate that mean UTCI values in the period 2000-2019 representative for thermal summer amount to $22.6^{\circ} \mathrm{C}$, thermal spring $9,9^{\circ} \mathrm{C}$, thermal autumn $8.4^{\circ} \mathrm{C}$, thermal winter $-10.4^{\circ} \mathrm{C}$, early spring $-4.6^{\circ} \mathrm{C}$, and early winter $-7.9^{\circ} \mathrm{C}$. For the periods with identified lack of thermal winter, mean UTCl value was $-6.6^{\circ} \mathrm{C}$. The aim of the present paper is an attempt to assess the variability of biothermal conditions as calculated using the UTCl index against the thermal seasons of the year in Szczecin.
\end{abstract}

\section{Key words}

$\mathrm{UTCl} \cdot$ weather perception - thermal seasons - biothermal stress

\section{Introduction}

The characteristic feature for the climate of Poland is a great variability of weather conditions and seasons (the date of the beginning and end, duration). The observed climate change is also manifested in the altered date of occurrence and duration of the seasons in a year. This is particularly manifested in the case of thermal winter (Piotrowicz, 2002; Czarnecka \& Nidzgorska-Lencewicz, 2017) and the transitional seasons (Piotrowicz, 2000b; Kossowska-Cezak, 2005; Woś, 2006; Dragańska et al., 2007; Franków, 2008; 
Nidzgorska-Lencewicz \& Mąkosza, 2008; Michalska, 2011). According to Kożuchowski and Żmudzka (2001), climate warming in Poland, which amounts to $0.9^{\circ} \mathrm{C}$ in 50 years, results from the increase in temperature at the turn of winter and spring (in February and March). Other authors also recognise the positive trend of air temperature in Poland manifested by increasingly warmer winter seasons (Lorenc, 2000; Boryczka, 2001; Trepińska, 2001; Kożuchowski, 2004). This is also acknowledged by Michalska (2011) who states that the highest increase in temperature over 10 years, i.e. from 0.3 recorded in the south of Poland to approximately $0.7^{\circ} \mathrm{C}$ in the north, is observed in February, followed by March, May and August. According to Michalska (2009, 2011), in the west of Poland and on the Polish coast, there is a positive trend in air temperature determined mostly by an increasing temperature in August. The summer warming observed in the last 25 years of the 20th century is also acknowledged by Michalska (2009, 2011) and Żmudzka (2010). The increasing trends of air temperature are manifested by particular changes in the occurrence of thermal seasons in a year. The results by Kożuchowski et al. (1999) show that the decreasing annual amplitude of air temperature in Poland results in shortening of the duration of, most of all, winter as well as summer and lengthening of the duration of the transitional seasons. Żmudzka (2004) stipulates that the changes are markedly more apparent in the west of the country, as compared to the eastern, cooler part of Poland. This is confirmed by Dragańska et al. (2007) who showed a lack of statistically significant trends of shortening or lengthening of the duration of thermal seasons in 1970-2000 in the northeast of Poland. According to Woś (2006), in the period 1951-2000 in Poznań, there was a marked trend of increasingly shorter winter seasons, lengthening of the spring season and early spring, and earlier dates of the beginning of spring and early spring.

The predictions concenring climate change envisage that an increase in temperature, both on a global as well as local scale, is to be manifested as an increase of thermal stress, particularly in the urban area (IPCC, 2014). Therefore, variability of thermal conditions due to climate warming will have its toll on the bioclimatic conditions (Błażejczyk et al., 2013). In this respect, it should be noted that both perception of thermal stress as well as the thermal stress itself stem not only from air temperature but are the function of the whole set of elements, such as radiation supply, air humidity or wind speed. Such a comprehensive approach and identification of the the way the atmospheric environment affects the health and quality of life of human is the foundation of bioclimatic studies. To assess the biothermal conditions, the literature on the subject applies complex indices based on models of heat exchange between the human body and the environment. The Universal Thermal Climate Index (UTCI) (Błażejczyk et al., 2010, 2013; Bröde et al., 2012), based on the multi-node model of heat transfer by Fiala et al. (2012), has been widely used recently. The available studies employ the UTCl index for the assessment of bioclimate both with respect to its temporal as well as spatial aspect (Błażejczyk \& Kunert, 2010; Lindner, 2011; Dobek et al., 2013; Błażejczyk et al., 2014, 2015a, 2015b, 2018; Mąkosza, 2013; Nidzgorska-Lencewicz \& Mąkosza, 2013; Nidzgorska-Lencewicz, 2015; Półrolniczak et al., 2016; Kuchcik, 2017; Rozbicka \& Rozbicki, 2018; Koźmiński \& Michalska, 2019).

Temporal as well as spatial analyses of the variability of biothermal conditions in Poland, based on the UTCI index (Kuchcik, 2017; Błażejczyk et al., 2020; Kuchcik et al., 2020; Krzyżewska et al., 2020; Wereski et al., 2020), demonstrate a decrease in UTCl value $<-13^{\circ} \mathrm{C}$ and an increase in $\mathrm{UTCl}>32^{\circ} \mathrm{C}$. Moreover, Kuchcik et al. (2020) points out the changes mainly in the minimum values $\left(1.3^{\circ} \mathrm{C}\right.$ per 10 years $)$ and mean values $\left(0.5^{\circ} \mathrm{C}\right.$ per years) of the UTCI index, and a negative trend of days with cold stress (4 days per 10 years) predominantly in the period November-March in the north-west of Poland and mountains area. 
As has already been mentioned, the present climate warming is consequential both to the occurrence of particular seasons in a year (date of the beginning and end, duration) as well as for the bioclimatic conditions. Arguably, the changes if the occurrence and duration of thermal seasons in a year, together with heat stress, affect the human organism.

For this reason, the present paper is an attempt to assess the variability of biothermal conditions as calculated using the UTCI index against the thermal seasons of the year in Szczecin.

\section{Materials and methods}

The study was made using hourly values (12 UTC) of the following meteorological elements: air temperature $\left({ }^{\circ} \mathrm{C}\right)$, relative air humidity (\%), wind speed $\left(\mathrm{m} \cdot \mathrm{s}^{-1}\right)$ and cloud cover (oct.) and mean monthly values of air temperature $\left({ }^{\circ} \mathrm{C}\right)$. Meteorological data was obtained from IMGW-PIB station in Szczecin for the years: 2000-2019. Szczecin is located in the northwest of Poland at the Odra River and Dabie Lake, at a distance of $65 \mathrm{~km}$, in a straight line, from the Baltic Sea. According to EPSON (European Observation Network for Territorial Development and Cohesion), it is one of the eight metropolitan areas in Poland

The assessment of bioclimatic conditions was conducted using the Universal Thermal Climate Index (UTCI) which is based on the analysis of human heat balance determined using a multi-node model of human heat transfer (Bröde et al., 2012; Fiala et al., 2012; Błażejczyk et al., 2013). This model comprises two subsystems of human heat transfer regulation: passive (taking into account the physical elements of heat transfer inside the human body as well as on body surface) and active (considering the physiological thermoregulatory mechanisms) (Fiala et al., 2012). UTCl index allows for an objective assessment of the bioclimatic conditions.

The UTCl index is defined as the air temperature $(\mathrm{Ta})$ of the reference condition causing the same model response as actual conditions, and expressed in $\left({ }^{\circ} \mathrm{C}\right)$. The UTCl index can be expressed as the following function (Błażejczyk et al., 2013):

$$
\mathrm{UTCl}=f(T a, v p, v a, d T m r t)
$$

where:

Ta - air temperature $\left({ }^{\circ} \mathrm{C}\right)$,

vp - water vapour pressure $(\mathrm{hPa})$,

$v a$ - wind speed at a height of $10 \mathrm{~m}$ above ground level $\left(\mathrm{m} \cdot \mathrm{s}^{-1}\right)$,

dTmrt-difference between mean radiation temperature and air temperature $\left({ }^{\circ} \mathrm{C}\right)$, where Tmr-mean radiation temperature, reflects values of temperature of a thin layer of air surrounding the human body

The calculation of the UTCI value was made o grounds of the hourly (12 UTC) values of the meteorological elements (air temperature, relative air humidity, wind speed and cloud cover), using BioKlima software, ver. 2.6 - https://www.igipz.pan.pl/ Bioklima-zgik.html

Particular thresholds of UTCI are based on the objective changes in the physiological parameters due to environmental conditions and constitute a measure of thermal stress on man (Tab. 1).

Table. $1 \mathrm{UTCl}$ assessment scale of thermal stress in man according Błażejczyk et al. (2013)

\begin{tabular}{|c|l|c|}
\hline $\begin{array}{c}\text { UTCl }\left[{ }^{\circ} \mathrm{C}\right] \\
\text { range }\end{array}$ & \multicolumn{1}{|c|}{$\begin{array}{c}\text { Thermal stress } \\
\text { category }\end{array}$} & Abbreviation \\
\hline$>46.0$ & extreme heat stress & EHS \\
38.1 to 46.0 & very strong heat stress & VSHS \\
32.1 to 38.0 & strong heat stress & SHS \\
26.1 to 32.0 & moderate heat stress & MHS \\
9.1 to 26.0 & no thermal stress & NTS \\
0.1 to 9.0 & slight cold stress & SLCS \\
-13.0 to 0.0 & moderate cold stress & MCS \\
-27.0 to -13.1 & strong cold stress & SCS \\
-40.0 to -27.1 & very strong cold stress & VSCS \\
$<-40.0$ & extreme cold stress & ECS \\
\hline
\end{tabular}

Additionally, mean monthly values of air temperature from January 2000 to December 2019 were used in the present study. 
The values were obtained from IMGW-PIB meteorological station in Szczecin, and were used to determine the dates of beginning and end and, consequently, duration of thermal seasons. Following Romer (1949), the present study adopts the generally acknowledged division of a year into individual thermal seasons which is commonly used in the literature on the subject (Piotrowicz, 2000a, 2006; Kossowska-Cezak, 2005; Olechnowic-Bobrowska \& Wojkowski, 2006; Woś, 2006; Dragańska et al., 2007; Czernecki \& Miętus, 2015):

- Winter $\quad\left(t<0^{\circ} \mathrm{C}\right)$,

- Early spring $\left(0^{\circ} \mathrm{C} \leq \mathrm{t}<5^{\circ} \mathrm{C}\right)$,

- Spring $\left(5^{\circ} \mathrm{C} \leq \mathrm{t}<15^{\circ} \mathrm{C}\right)$,

- Summer $\left(t \geq 15^{\circ} \mathrm{C}\right)$,

- Autumn $\left(15^{\circ} \mathrm{C}>\mathrm{t} \geq 5^{\circ} \mathrm{C}\right)$,

- Early winter $\left(5^{\circ} \mathrm{C}>\mathrm{t} \geq 0^{\circ} \mathrm{C}\right)$.

The calculations were made using the following equation by Gumiński (Gumiński, 1948; Kossowska-Cezak et al., 2005; Dragańska et al., 2007; Czernecki \& Miętus, 2015) for the rising $\left(x_{1}\right)$ and falling $\left(x_{2}\right)$ phase of the mean temperature:

$$
\begin{aligned}
& x_{1}=\frac{t_{p}-t_{1}}{t_{2}-t_{1}} n \\
& x_{2}=\frac{t_{1}-t_{p}}{t_{1}-t_{2}} n
\end{aligned}
$$

where:

$t_{p}$ - threshold value,

$t_{1}$ - monthly mean temperature in the month preceding the crossing of the threshold value,

$t_{2}$ - monthly mean temperature in the following month having exceeded the threshold value,

$n$ - number of days in the previous month,

$x_{1}, x_{2}-$ number of days to be added to the 15 th day of the previous month.

Considering the number of years during which the thermal winter $\left(\mathrm{t}<0^{\circ} \mathrm{C}\right)$, identified according to the adopted methodology, was not recorded in the period 2000-2019, in the present study the respective period is termed no thermal winter (NTW). This results from the fact that it was impossible to determine the specific dates of the periods before and immediately following such winter seasons, such as early winter or early spring, all of which fall within air temperature values from 0 to $5^{\circ} \mathrm{C}$. Similar assumptions were made in a study by Franków (2008).

\section{Results}

In the analysed period of 2000-2019, mean values of UTCl index calculated for 12:00 UTC (widely adopted as being representative for the day time) were from 4.9 in 2010 to 10.4 ${ }^{\circ} \mathrm{C}$ in 2018 , which gives an average of $7.7^{\circ} \mathrm{C}$ (Fig. 1). With respect to biothermal stress, these values represent slight cold stress and no thermal stress. At the same time, the minimum and maximum UTCl values showing the range of possible fluctuations are -44.0 in January 2010 and $40.5^{\circ} \mathrm{C}$ in August 2015 . This indicates the possibility of the occurrence of conditions connected with extreme cold stress and very strong heat stress in Szczecin. In the period under analysis, the conditions causing extreme heat stress were not recorded. In turn, on a monthly basis, the average lowest UTCI values were recorded in January $-10.7^{\circ} \mathrm{C}$, and by far the highest values were recorded in July $-24.0^{\circ} \mathrm{C}$. The largest range of UTCI fluctuations was identified in the winter months December-March, and the smallest in June and November (Fig. 1).

The data presented in Table 2 and Figure 2 shows that on average the longest thermal season in the period 2000-2019 in Szczecin is summer (106 days), and the shortest is early spring ( 26 days). On average, summer is recorded in Szczecin from May 26 to September 8 . However, there were years in which the beginning of the thermal summer was recorded as early as May 3 (2018) or as late as June 20 (2004).

Mean UTCI values of the thermal summer in the analysed multiannual period is $22.4^{\circ} \mathrm{C}$, yet the values are only slightly different in the subsequent years - from $20.6^{\circ} \mathrm{C}$ to $24.9^{\circ} \mathrm{C}$ in 2011 and 2001. The year 2011 was marked by above average duration of the thermal summer, which amounted to 118 days, and was the third longest summer period 


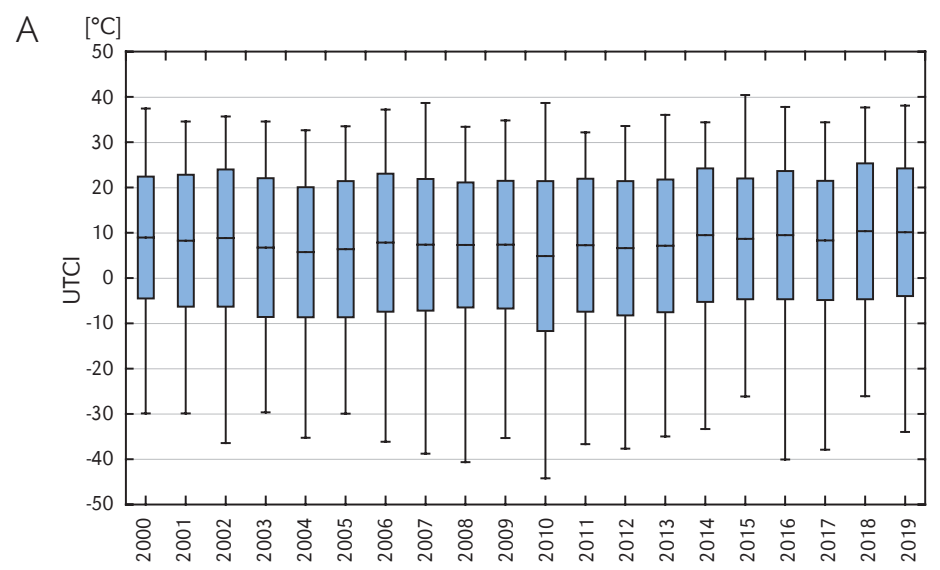

B

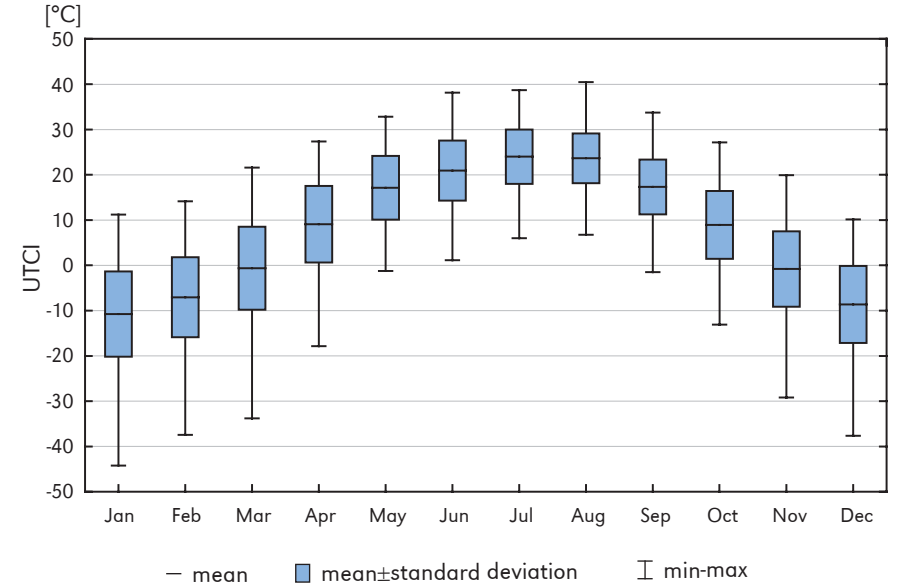

Figure 1. Annual (A) and monthly (B) mean, maximum and minimum UTCl values in Szczecin, 2000-2019

Table 2. Basic characteristics of thermal seasons in Szczecin, 2000-2019

\begin{tabular}{|l|c|c|c|c|c|c|}
\hline \multirow{2}{*}{ Thermal season } & \multicolumn{3}{|c|}{ Start Date } & \multicolumn{3}{c|}{ Length } \\
\cline { 2 - 7 } & mean & earliest & latest & mean & longest & shortest \\
\hline Early spring & $21 \mathrm{II}$ & $17 \mathrm{I}$ & $18 \mathrm{III}$ & $18 / 26^{\star}$ & 58 & $7^{\star}$ \\
Spring & $15 \mathrm{III}$ & $15 \mathrm{II}$ & $3 \mathrm{IV}$ & 68 & 104 & 38 \\
Summer & $26 \mathrm{~V}$ & $3 \mathrm{~V}$ & $20 \mathrm{VI}$ & 106 & 138 & 78 \\
Autumn & $9 \mathrm{IX}$ & $25 \mathrm{VIII}$ & $29 \mathrm{IX}$ & 71 & 110 & 52 \\
Early winter & $19 \mathrm{XI}$ & $2 \mathrm{XI}$ & $23 \mathrm{XII}$ & $31 / 40^{\star}$ & 54 & $9^{\star}$ \\
Winter & $3 \mathrm{I}$ & $1 \mathrm{XII}$ & $16 \mathrm{I}$ & $33 / 48^{\star}$ & 94 & $11^{\star}$ \\
No thermal winter & $30 \mathrm{XI}$ & $8 \mathrm{XI}$ & $17 \mathrm{I}$ & $38 / 72^{\star}$ & 130 & $47^{\star}$ \\
\hline
\end{tabular}

* average calculated based on real days occuring 


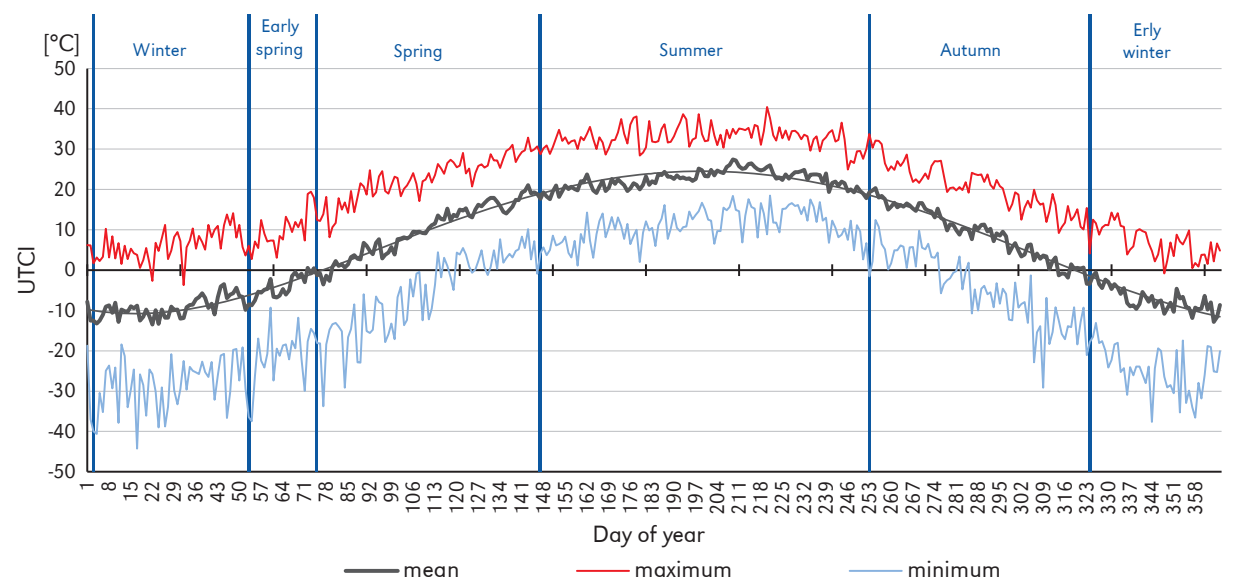

Figure 2. UTCl values and average dates of thermal seasons in Szczecin, 2000-2019

in the years 2000-2019. On more than 75\% of days, the occurrence of thermoneutral conditions was recorded, and on more than $21 \%$ of days moderate heat stress. In turn, in 2001, the thermal summer was found to be the second shortest in terms of duration with lack of thermal stress on approximately 55\% of days - moderate heat stress was observed on $37 \%$ of days. In spite of short thermal summer there was a strong heat stress $(7.6 \%$ of days). The range of UTCl values in the years 2000-2019 for thermal summer was $40.5^{\circ} \mathrm{C}$ and $1.1^{\circ} \mathrm{C}$. Generally, in the summer period the predominant were the days with no thermal stress $(68 \%)$ and moderate heat stress (25\%). Strong heat stress and moderate cold stress were reported with frequencies of 5 and $2 \%$ of days. It must be emphasized that the highest number of days with strong heat stress, i.e. 13, that was almost three times higher than the average, was recorded during the one before last of the analysed thermal summer in year 2018. Moreover, there were sporadic cases of days on which there was a very strong heat stress (Tab. 3, Fig. 3-5).

In terms of the average duration in the analysed period, thermal autumn is the second season (71 days) and its duration can vary from 52-110 days (Tab. 2). It begins, on average, on September 9 and ends on November 18 , yet the date of the end of the thermal autumn shows greater variation.
Table 3. UTCI values in thermal seasons of a year in Szczecin, 2000-2019

\begin{tabular}{|l|r|c|r|}
\hline \multirow{2}{*}{ Thermal seson } & \multicolumn{3}{|c|}{ UTCI $\left[{ }^{\circ} \mathrm{C}\right]$} \\
\cline { 2 - 4 } & mean & maximum & minimum \\
\hline Early spring & -4.6 & 18.0 & -33.3 \\
Spring & 9.9 & 32.8 & -29.1 \\
Summer & 22.6 & 40.5 & 1.1 \\
Autumn & 8.4 & 33.7 & -29.2 \\
Early winter & -7.9 & 15.1 & -40.0 \\
Winter & -10.4 & 11.4 & -44.2 \\
No thermal winter & -6.6 & 18.9 & -40.6 \\
\hline
\end{tabular}

Mean UTCl values for thermal autumn amount to $8.4^{\circ} \mathrm{C}$, the maximum being $33.7^{\circ} \mathrm{C}$ and the minimum $-29.2^{\circ} \mathrm{C}-\mathrm{Tab}$. 3. However, it should be noted that the aforementioned values are the most varied UTCI values out of all analysed thermal seasons in the period 2000-2019. The highest UTCI value $-15^{\circ} \mathrm{C}$, was identified during the thermal autumn with the earliest date of beginning, i.e. August 25 of 2016. Mostly, during thermal autumn, lack of thermal stress is recorded most frequently - almost on $48 \%$ of all days, followed by slight cold stress (31\%) and moderate cold stress (17\%). Additionally, there frequency of other classes is recorded very rarely $(2 \%$ of days) - strong cold stress, moderate heat stress, sporadically strong heat stress and very strong cold stress (Fig. 3-5). 


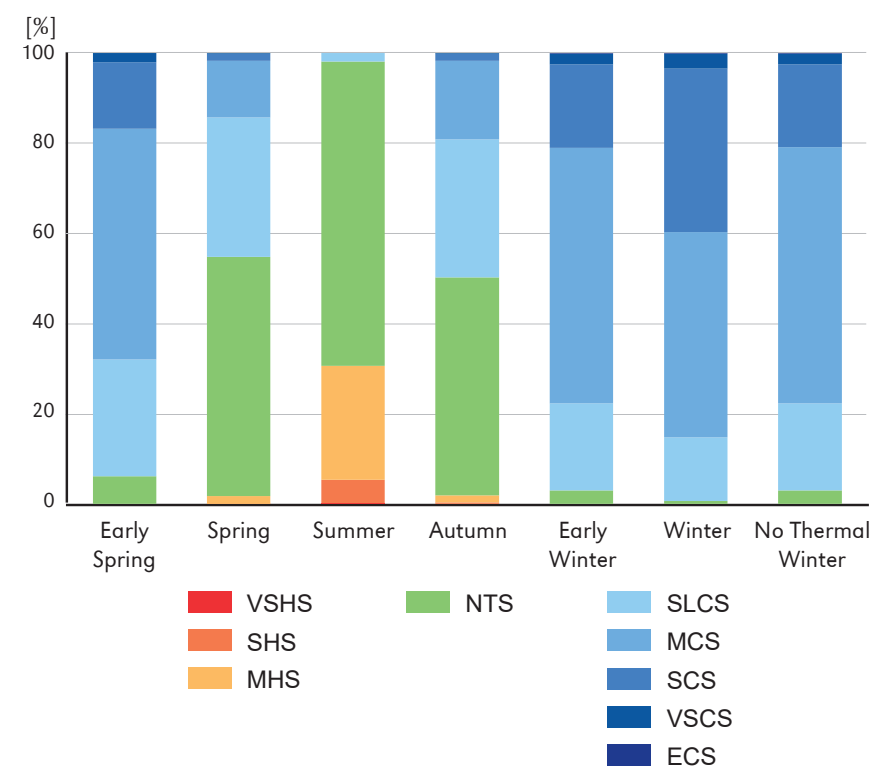

Figure 3. Frequency of thermal stress category in thermal seasons according to UTCl in Szczecin, 20002019

Duration of thermal spring is comparable to that of thermal autumn (Tab. 2, Fig. 2). Thermal spring in Szczecin in the period 2000-2019 shows a duration of, depending on individual years, from 38 (2018) to 104 (2014) days, with an average of 68 days. In each year of the analysed multiannual period, there is a definite shared period in which the thermal spring was recorded. Kossowska-Cezak (2005) termed the period as the absolute thermal spring. In Szczecin, it is recorded from April 3 to May 2.

Spring is characterised by the occurrence of conditions corresponding to thermal comfort (saving conditions) on 55\% of days, on $30.4 \%$ there is a slight cold stress, and on $11.3 \%$ of days moderate cold stress is recorded. The comparison of spring with autumn shows a slightly less frequent occurrence of conditions corresponding with no thermal stress. Slight cold stress is recorded with a comparable frequency, and moderate cold stress less frequently. In the spring seasons under analysis, strong cold stress and moderate heat stress was found on 1.6 and $1.4 \%$ of days, very strong cold stress and strong heat stress only on $0.1 \%$ of days. Mean
UTCI values are higher in spring, as compared to autumn, and amount to $10.3^{\circ} \mathrm{C}$, whereas the extreme values are comparable (Fig. 3-5).

Thermal winter is marked by a decrease in mean 24-hour air temperature below $0^{\circ} \mathrm{C}$. On average, it lasts 33 days - taking into consideration all of the years under analysis, or slightly longer, i.e. 48 days - taking into consideration only the periods with actual occurrence of thermal winter (13 out of 19 analysed winter seasons). The period with recorded lack of thermal winter in Szczecin shows a high variability with respect to duration and can range from 47 to 130 days depending on a year - Tab. 2 .

$\mathrm{UTCl}$ values for thermal winter are average $-10.4^{\circ} \mathrm{C}$ (Tab. 3), ranging from $11.4^{\circ} \mathrm{C}$ in the winter of $2012 / 2013$ to $-44.2^{\circ} \mathrm{C}$ in the winter of $2009 / 2010$. The lowest mean $\mathrm{UTCl}$ values were recorded in the winter of $2009 / 2010\left(-15.9^{\circ} \mathrm{C}\right)$, and the highest in the winter of $2015 / 2016\left(-4.8^{\circ} \mathrm{C}\right)$. Moderate cold stress (45.4\%) and strong cold stress $(36.3 \%)$ were recorded by far most frequently, in total on more than $81.7 \%$ of days. A significant share of days showed a slight 


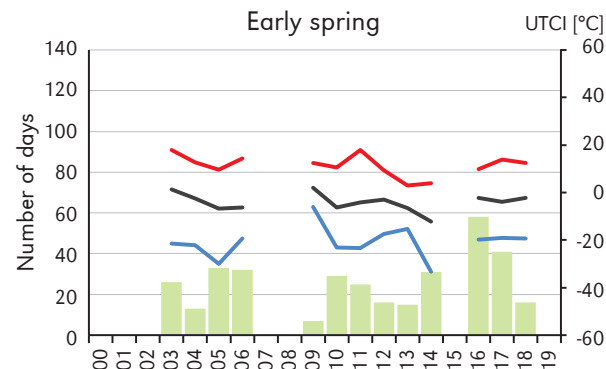

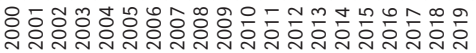
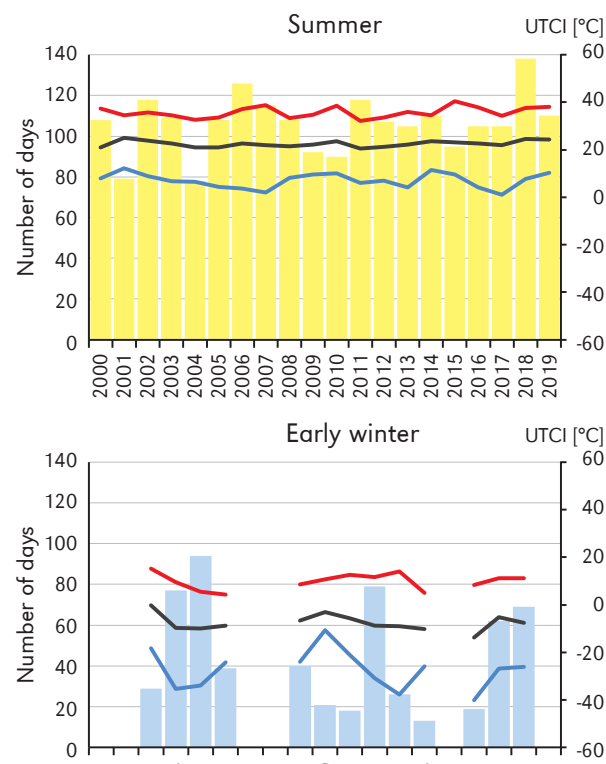

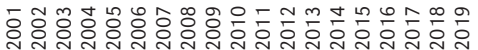

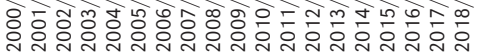

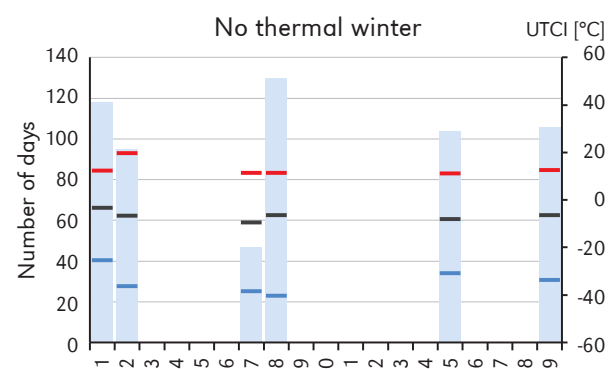

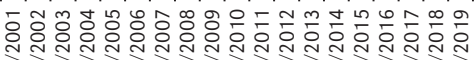

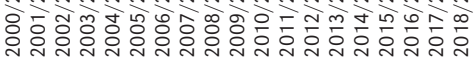
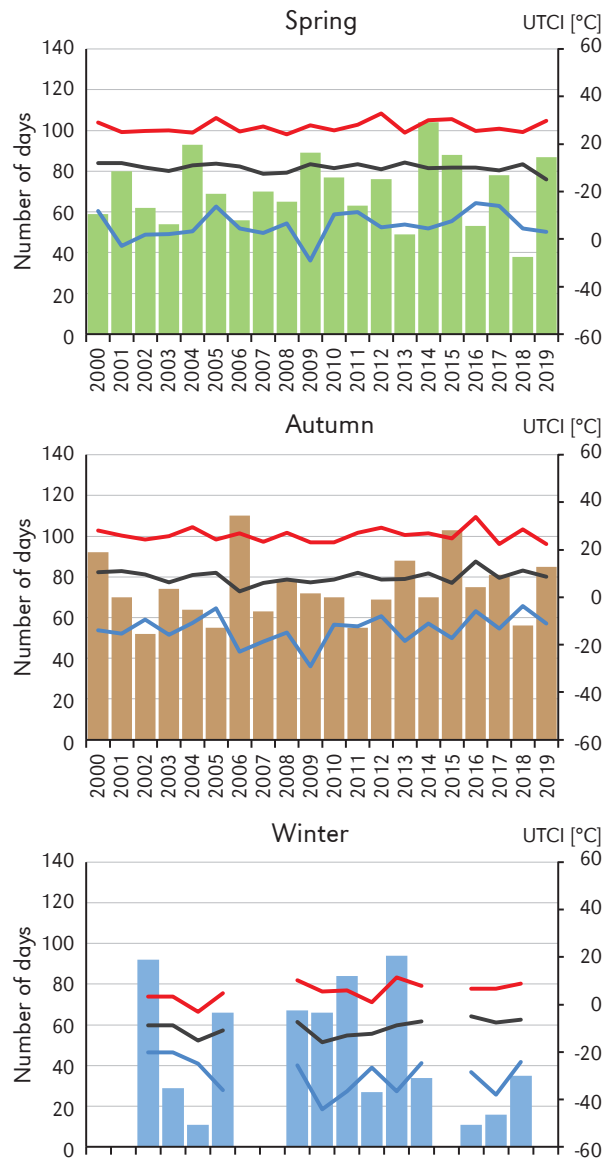

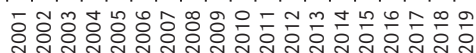

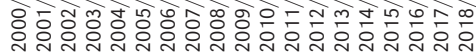

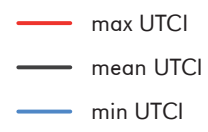

Figure 4. Number of days in thermal seasons (bars) in Szczecin and mean, maximum and minimum UTCI values, 2000-2019 

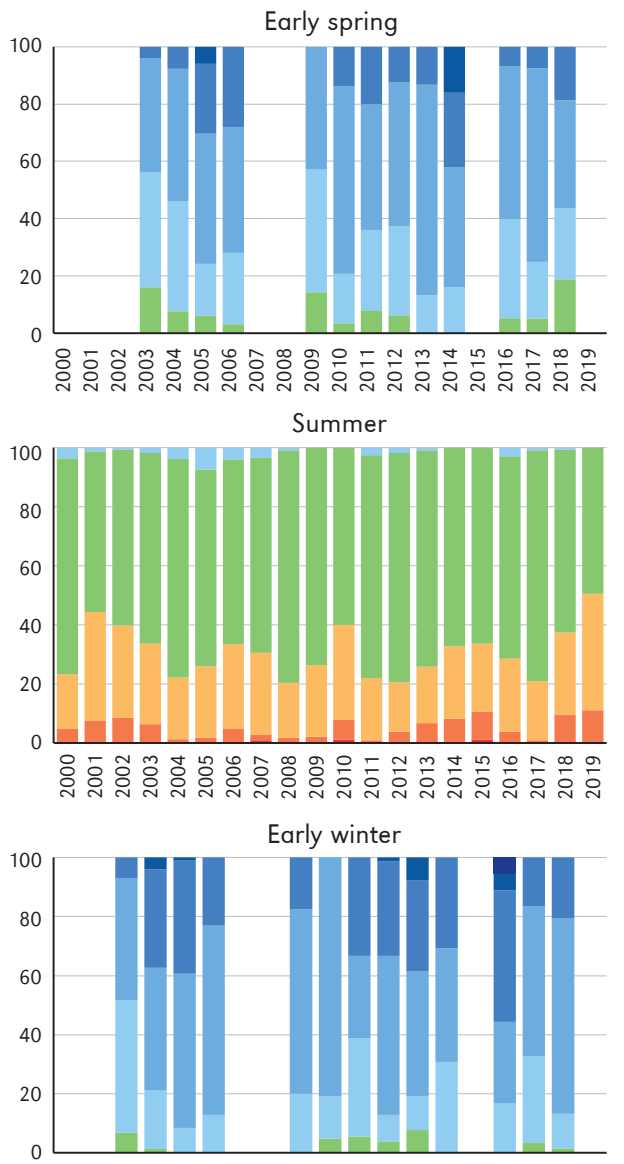

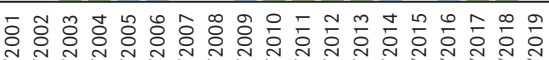

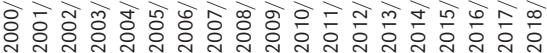

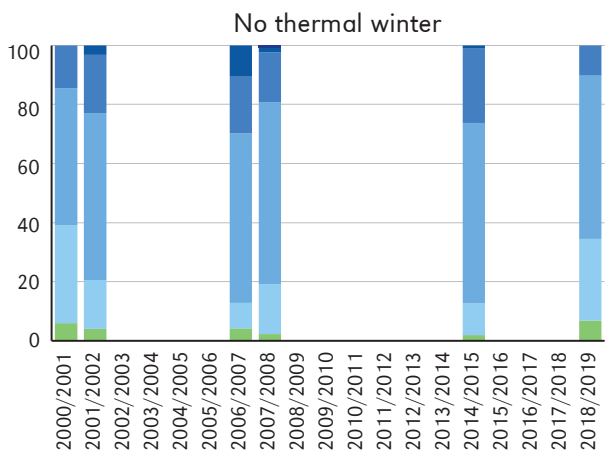

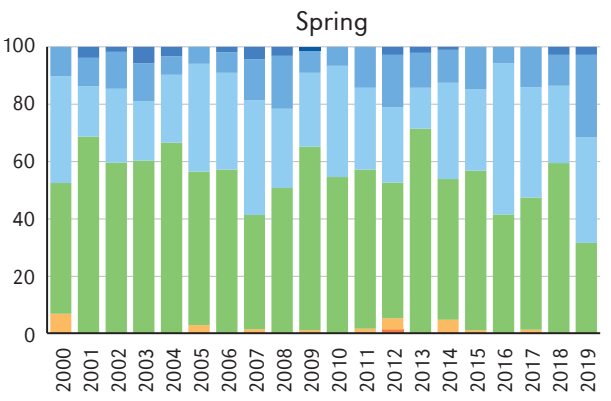

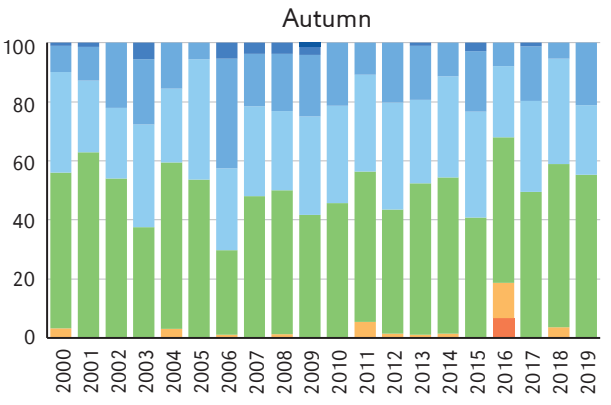

Winter
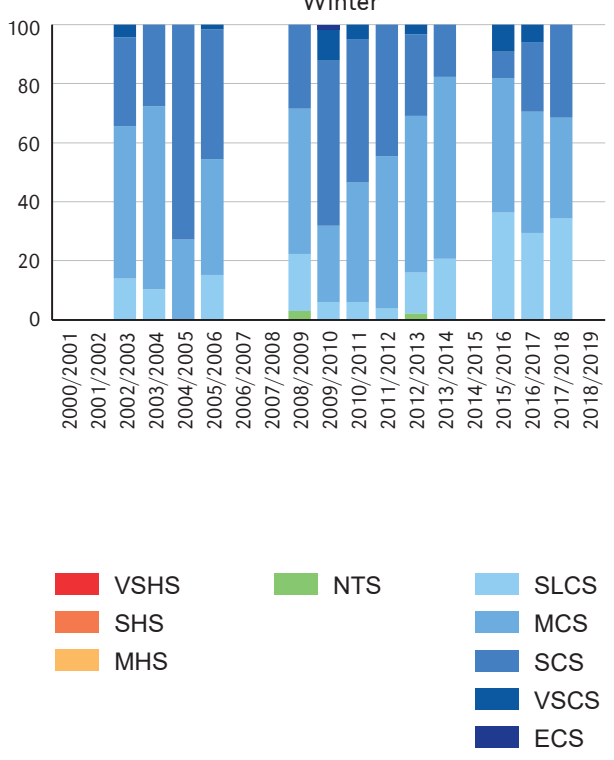

Figure 5. Frequency of thermal stress categories according to UTCI in Szczecin, 2000-2019 
cold stress (14.2\%). Only in few cases there was a very strong cold stress $\left(3.3^{\circ} \mathrm{C}\right)$, and no thermal stress and very strong cold stress was recorded even less frequently $\left(0.2^{\circ} \mathrm{C}\right)$. The frequency and range of thermal stress is dependent on the season of a year. In the analysed period there were thermal winters with only two classes of thermal stress (strong and moderate) - in the shortest winter period of 2004/2004. There were also winters with all thermal classes - 2009/2010 and 2012/2013 (Fig. 3-5).

Mean UTCl value during the lack of thermal winter $-6.6^{\circ} \mathrm{C}$, and the highest and lowest mean values are $18.9^{\circ} \mathrm{C}$ and $-40.6^{\circ} \mathrm{C}$ (Tab. 3). Thermal stress on days with lack of thermal winter was, predominantly, moderate stress (55\%) and slight and strong cold stress - 20 and $18.2 \%$, respectively. For example, in the conditions of a lack of thermal winter in the years 2000/2001 and 2018/2019, there was a significantly higher share of days with slight thermal stress. In turn, in the period 2014/2015, the share of moderate cold stress was slightly more frequent (Fig. 3-5).

The transitional seasons, namely early winter and early spring, are connected with the occurrence or thermal winter just as with the lack of such. The occurrence of actual early winter in Szczecin is recorded, on average, from November 19 to January 2. On average, the duration of actual early winter is 40 days, and is longer by 14 days than early spring (Tab. 2).

Mean UTCl values for early winter is $-7.9^{\circ} \mathrm{C}$, with the extreme values of 15.1 and -40 (Tab. 3). During the occurrence of thermal early winter, the conditions representative for moderate cold stress (52.2\% of days) were predominant. Strong and slight cold stress amount to 26.6 and $17.5 \%$ of days, respectively. Very strong cold stress was recorded on $1.4 \%$ of days, and extreme cold stress on only $0.2 \%$. Furthermore, the no thermal stress during thermal early winter was found only on $2.2 \%$ of days (Fig. 3-5).

The shortest average duration of thermal season was identified for early spring (Tab. 2, Fig. 2). The beginning of this transitional season is strongly determined by the end of winter and shows a high variability of as much as 2 months - the earliest beginning of early spring is January 17, and the latest March 19. The longest duration of early spring was recorded in 2016 and 2017. Additionally, a tendency of earlier beginning of early spring was identified

In the period of thermal early-spring, the average value was $-4.6^{\circ} \mathrm{C}$, i.e. markedly higher than for early winter (with the same range of air temperature values used for determination of thermal seasons). Similarly, slightly higher extreme values were identified. With respect to thermal stress in early spring, the distribution shows similarity to early winter. However, as can be observed, the number of days with slight cold stress and no thermal stress is slightly higher, and the conditions representative for strong and moderate cold stress are recorded less frequently. Sporadic, however more frequent than in early winter, occurrence of very cold stress class is observed (Tab. 3, Fig. 3-5).

Figure 6 shows the relationship between the selected UTCI annual values (mean, max, min) and the dates of the beginning, end and duration of the thermal seasons.

It was found that the average annual UTCI values show the closest negative correlation with the beginning, end and duration of autumn and early winter and positive corelation with the dates beginning of spring. Whereas, the maximum annual UTCI values indicated a positive correlation with the dates of the end and duration of spring and thrmal winter, and a negative correlation with the dates of the beginning of spring and winter. In turn, the analysis of minimum UTCI values showed positive relationships between the dates of the beginning of thermal summer, early spring and winter and end dates of thermal summer and winter. Negative correlation was found for the start dates of early winter and end date of early spring, spring, autumn and early winter as well as duration of early spring, spring, early winter, autumn and thermal summer. 
Start date
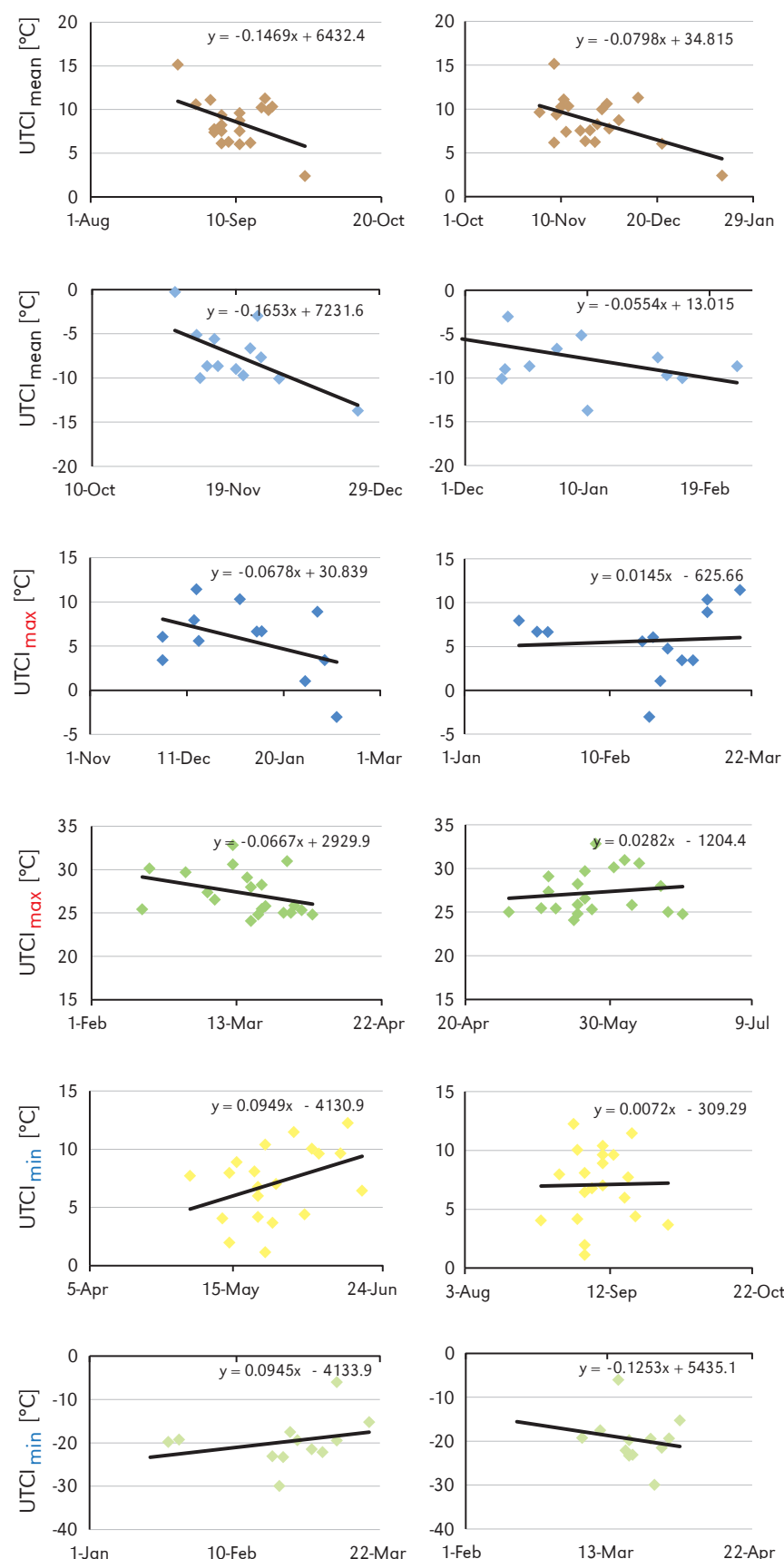

End date
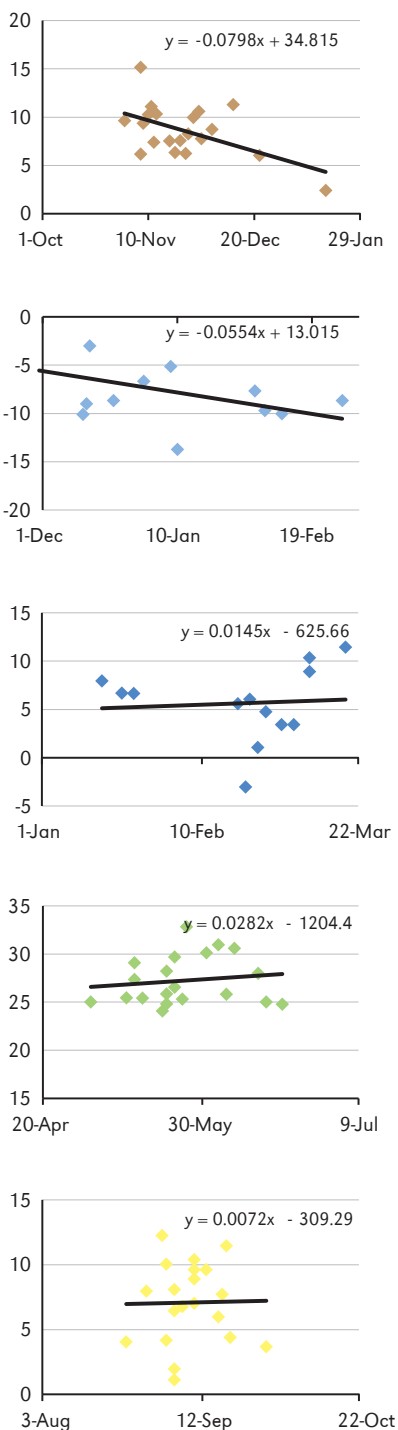
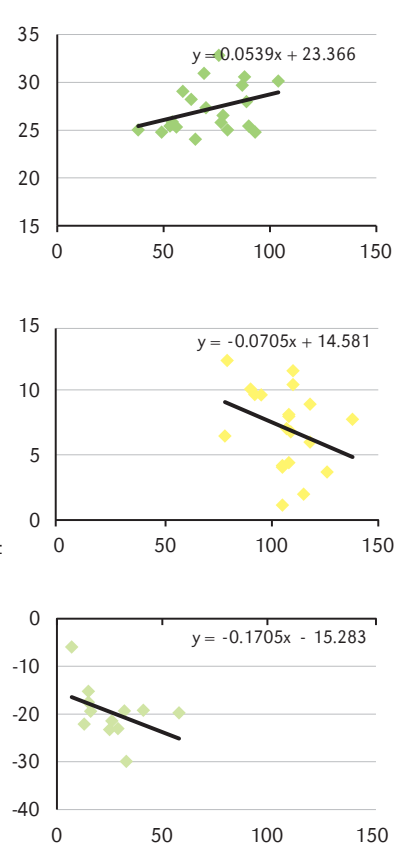

$\rightarrow$ Autumn $\diamond$ Erly Winer
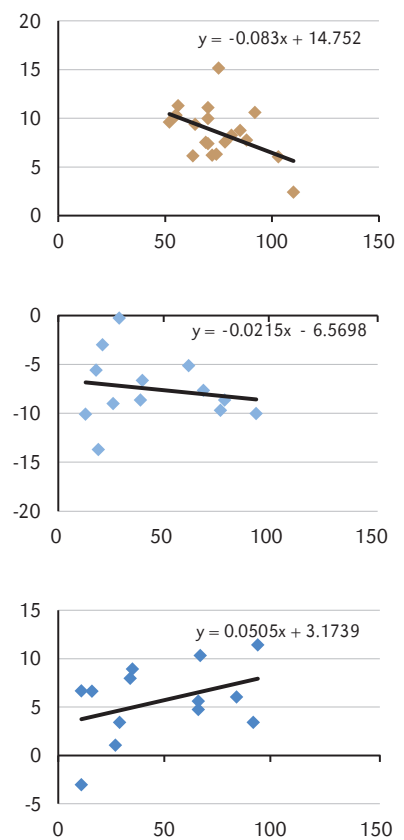

Figure 6. The relationship between the selected UTCl annual values (mean, max, min) and the date of the beginning, end and duration of thermal seasons in Szczecin, 2000-2019 


\section{Discussion}

Obtained results are fully in line with the general trend of changes in the thermal seasons of a year (Kożuchowski \& Żmudzka, 2001; Jaagus et al., 2003; Degirmendžić et al., 2004; Koźmiński \& Michalska, 2004; Kożuchowski \& Degirmendžić, 2005; BACC, 2008; Czernecki \& Miętus, 2015) which, according to Żmudzka (2004), are more pronounced in the west of Poland than in the east. The present analysis of duration of thermal seasons in a year shows an earlier occurrence of early spring, spring and summer and later dates of the beginning of autumn, early winter and winter. Similar results with respect to the direction of changes of the thermal seasons in a year are presented in studies which analyse the years 19612007 in the Szczecin Lowland (Nidzgorska \& Mąosza, 2009), or in studies concerning the whole area of Poland for the years 1951-2010 (Czarnecki \& Miętus, 2015).

Czarnecka and Nidzgorska-Lencewicz (2017) state that in the western part of Poland, the frequency of occurrence of winter in years 1960-2015 determined with mean monthly temperature, does not exceed $80 \%$, and on the Szczecin Lagoon is below 70\%. This was confirmed by Czernecki and Miętus (2015) who found that in the years 1951-2010, thermal winter was not recorded in $10 \%$ of the cases and in in the region of the Baltic Sea in 22\% of cases. In the analysed years: 2000-2019 in Szczecin, thermal winter was observed in $68 \%$ of cases, and its average duration was 48 days. Similarly, Nidzgorska-Lencewicz and Mąkosza (2008) demonstrated that in the period 1961-2009 in the Szczecin Lowland, duration of thermal winter fluctuated from 5 to 109 days, with a clearly pronounced statistically significant trend of increasingly shorter winter period which, according to authors, on average are shorter by 11 days for every 10 years. These findings are confirmed by the results by Koźmiński (1983) and Koźmiński et al. (2007) who indicated that in the period 1956-1980 the duration of thermal winter in the vicinity of Szczecin, on average, was
75 days and in the period 1961-2000 only 54 days.

The results presented here demonstrate the increasingly more frequent occurrence of periods without thermal winter, which in turn results in a longer duration of the preceding as well as subsequent season, i.e. early winter and early spring. The average duration of a period without thermal winter in Szczecin amounted to 38 days. Lengthening of the duration of these two seasons for the whole country was demonstrated by Czernecki and Miętus (2015) who additionally indicated equalling of the duration of early winter and early spring in the future. Numerous studies on thermal seasons point to the fact that summer is the season with the longest duration. The analysis of thermal seasons shows that the longest season observed in Szczecin in 2000-2019 was thermal summer with the absolute duration in each year under analysis from June 20 to August 24. The average number of summer days is 106 . Moreover, the available literature, concerning different periods, observes the increasing trend of the number of summer days with air temperature $>15^{\circ} \mathrm{C}$ (Nidzgorska-Lencewicz \& Mąkosza, 2008; Szyga-Pluta, 2011; Majewski \& Przewoźniczuk, 2014; Czernecki \& Miętus, 2015). The results obtained for Szczecin in the period 2000-2019 are in line with such observations, and the recorded increase in the number of summer days was 0.6 day per year. However, it must be emphasized that in the analysed period, the summer period was shorter than 100 days only in 5 years. The occurrence of summer periods with duration of more than 100 days is also reported by Czernecki and Miętus (2015) and Majewski and Przewoźniczuk (2014).

The analysis of the bioclimatic conditions presented here aims to determine the range and frequency of the possible thermal stress in the period 2000-2019 in Szczecin. It was calculated that the average yearly UTCI value in the analysed period was $7.8^{\circ} \mathrm{C}$, however it may range from 4.9 to $10.4^{\circ} \mathrm{C}$ - representing slight cold stress and no thermal stress. Lower UTCl values for Szczecin, amounting 
to $6.6^{\circ} \mathrm{C}$, were calculated by Kuchcik et al. (2013) for he years 1991-2000, that is for the decade preceeding the analysed period. Moreover, the simulations of future changes of bioclimatic conditions for Poland by Błażejczyk et al. (2015) show that in the next decades of the 21st century, mean annual UTCI values are to increase gradually. According to the authors, the values can increase to $8.8^{\circ} \mathrm{C}$ or even to $10.6^{\circ} \mathrm{C}$, depending on the adopted scenario of climate change. The extreme values are of vital importance in the analysis of the bioclimatic conditions. The highest and the lowest UTCI values are crucial for the frequency of occurrence of the extreme thermal stress, especially given the present climate warming. According to the conducted simulations of the changes of the bioclimatic conditions by Błażejczyk et al. (2015), a gradual increase is also to be observed with respect to the maximum values of UTCl index which may increase to 42.2 or $43.6^{\circ} \mathrm{C}$ (value approx. $39.7^{\circ} \mathrm{C}$ in the reference period). Threshold values in particular categories of heat stress according to UTCl were determined based on critical levels of physiological responses (Bröde et al., 2012; Błażejczyk et al., 2013). In the period 2000-2019 in Szczecin, the possible range of fluctuation of UTCI values was from -44.0 in January 2010 to $40.5^{\circ} \mathrm{C}$ in August 2015. This indicates the possibility of the occurrence of heat stress from extreme cold stress and very strong heat stress. In their study on the extreme UTCl values in Poland regarding the warm half-year from the period 1966-2015, Tomczyk and Owczarek (2020) found that the highest UTCI values were from $37.2^{\circ} \mathrm{C}$ in the foothills of the Tatra mountains to $43.1^{\circ} \mathrm{C}$ recorded in Stubice station in the west of Poland. The values obtained by the authors also suggest lack of the extreme heat stress according to UTCl assessment scale. It should be mentioned that, with respect to high compliance of UTCl with another index, i.e. PET (Błażejczyk et al., 2012), that the threshold of heat stress of extreme intensity is lower than $46^{\circ} \mathrm{C}$. This is manifested by the results obtained by Błażejczyk et al. (2018) and Kuchcik et al. (2013), showing an increase in the mean daily mortality rates in Polish cities at values of at last $32^{\circ} \mathrm{C}$. A study by Urban and Kysely (2014) reports a $12-13 \%$ increase in cardiovascular mortality in the Czech Republic at UTCI higher than $22^{\circ} \mathrm{C}$. According to Kuchcik (2006), in the hottest and longestheat waves in Poland, the risk of death can increase by $33-37 \%$. In the analysed period in Szczecin, strong and very strong heat stress (UTCl > 32) was recorded with the frequency of 1.5\% (5 days) and $0.3 \%$ (1 day) respectively, and strong and very strong cold stress 8 and $0.8 \%$ of days. As indicated Błażejczyk et al. (2015), the total number of days with strong cold stress and strong heat stress in Szczecin is 8\% in a year. According to Tomczyk and Owczarek (2020), mean number of days in the years 1966-2015 with strong and very strong heat stress in Poland is from approx. 2 days in the Baltic coast and to approx. 5 days in the central part of Poland. However, as indicated by Błażejczyk et al. (2015) and Kuchcik (2017), in years 19732014, the number of days with strong heat stress showed an increasing trend and high variability from one year to another ranging from 1 to 21 days. In Szczecin, the calculated year-to-year fluctuation range of the number of days with strong heat stress is also high and amounts to 1-13. The results presented in this paper correspond with the data given in the literature on the subject.

The analysis of the annual number of days characterised by biothermal stress shows that in Szczecin, the highest number of days (147 in a year $-40.8^{\circ} \mathrm{C}$ ) is marked by lack of thermal stress on grounds of UTCl. Such a distribution of days in a year, where the lack of thermal stress is predominant, is emphasized in numerous studies on biothermal conditions with reference to various regions in Poland, regardless of the periods of the analysed. For example, on the coast of the Baltic Sea, the share of such days in approx. 27-42\% (Półrolniczak et al., 2016, Koźmiński \& Michalska, 2019), in Warszawa 43-67\% (Lindner, 2011; Rozbicka \& Rozbicki, 2018), in Białystok from 9 to 42,3\% (Kuchcik, 2017), in Gorzów Wielkopolski, Zielona Góra and 
Słubice from 36 to 40\% (Mąkosza, 2013) and in Lesko and Lublin respectively 35-37,8\% (Dobek et al., 2013; Nowosad et al., 2013).

The present study provides an additional characteristics of biothermal conditions using UTCl index with respect to individual thermal seasons in a year identified according to the method by Gumiński (1948). The literature on the subject lacks studies with such an approach to this matter. The frequency distribution or UTCl values in climatological seasons in Poland is presented according to the adopted rule of three months' duration e.g. spring March-May or summer June-September etc. With this approach in mind, in winter strong and moderate cold stress is predominant, in summer - the most predominant is lack of thermal stress, and in autumn and spring - from lack of thermal stress to moderate cold stress (Mąkosza, 2013; Kuchcik et al., 2013; Nidzgorska-Lencewicz, 2015; Półrolniczak et al., 2016; Kuchcik, 2017; Rozbicka \& Rozbicki, 2018; Koźmiński \& Michalska, 2019).

Editors' note:

Unless otherwise stated, the sources of tables and figures are the authors', on the basis of their own research.

\section{References}

BACC author team (2008). Assessment of climate change for the Baltic sea basin. Berlin: Springer-Verlag. BioKlima software 2.6 - https://www.igipz.pan.pl/Bioklima-zgik.html

Błażejczyk, A., Błażejczyk, K., Baranowski, J., Kuchcik, M. (2018). Heat stress mortality and desired adaptation responses of healthcare system in Poland. International Journal of Biometeorology, 62, 307-318. https://doi.org/10.1007/s00484-017-1423-0

Błażejczyk, K., Baranowski, J., Błażejczyk, A. (2015). Wpływ klimatu na stan zdrowia w Polsce: stan aktualny oraz prognoza do 2100 roku. Warsaw: Wydawnictwo Akademickie SEDNO.

Błażejczyk, K., Błażejczyk, A., Baranowski, J., Kuchcik, M. (2020). Assessment of mortality risk in Poland due to cold and heat stress and predictions to 2100. Journal of Climate Change Research, 1(4), 49-57. 10.30488/ccr.2020.252534.1028

Błażejczyk, K., Bröde, P., Fiala, D., Havenith, G., Holmér, I., Endritzky, G., Kampmann, B. (2010). UTCl nowy wskaźnik oceny obciq̨żeń cieplnych człowieka. Przegląd Geograficzny, 82(1), 49-71. https://doi.org/10.7163/PrzG.2010.1.2

Błażejczyk, K., Jendritzky, G., Bröde, P., Fiala, D., Havenith, G., Epstein, Y., Psikuta, A., Kampmann, B. (2013). An introduction to the universal thermal climate index (UTCI). Geographia Polonica, 86(1), 5-10. https://doi.org/10.7163/GPol.2013.1

Błażejczyk, K., Kuchcik, M., Milewski, P., Dudek, W., Kręcisz, B., Błażejczyk, A., Szmyd, J., Degórska, B., Pałczyński, C. (2014). Miejska wyspa ciepła w Warszawie uwarunkowania klimatyczne i urbanistyczne. Warsaw: Wydawnictwo Akademickie SEDNO.

Błażejczyk, K., Kunert, A. (2010). Warunki bioklimatyczne wybranych aglomeracji Europy i Polski. In E. Bednorz, L. Kolendowicz (Eds.), Klimat Polski na tle klimatu Europy. Zmiany ich konsekwencje (pp. 93-106). Studia i Prace z Geografii i Geologii, 16.

Boryczka, J. (2001). Klimat Ziemi: przeszłość, teraźniejszość, przyszłość. Prace i Studia Geograficzne, 29, 55-72.

Bröde, P., Fiala, D., Blazejczyk, K., Holmer, I., Jendritzky, G., Kampmann, B., Tinz, B., Havenith, G. (2012). Deriving the operational procedure for the Universal Thermal Climate Index (UTCI). International Journal of Biometeorology, 56, 481-494. https://doi.org/10.1007/s00484-011-0454-1 
Czarnecka, M., Nidzgorska-Lencewicz, J. (2017). Zmienność termicznej zimy w Polsce w latach 1960-2015. Acta Agrophysica, 24(2), 205-220.

Czernecki, B., Miętus, M. (2015). The thermal seasons variability in Poland, 1951-2010. Theoretical and Applied Climatology, 127, 481-493. https://doi.org/10.1007/s00704-015-1647-z

Degirmendžić, J., Kożuchowski, K., Żmudzka, E. (2004). Changes of air temperature and precipitation in Poland in the period 1951-2000 and their relationship to atmospheric circulation. International Journal of Climatology, 24, 291-310. https://doi.org/10.1002/joc.1010

Dobek, M., Demczuk, P., Nowosad, M. (2013). Zróżnicowanie przestrzenne wskaźnika UTCI w Lublinie w określonych scenariuszach pogodowych. Annales Universitatis Mariae Curie-Skłodowska, Sectio B, Geographia, Geologia, Mineralogia et Petrographia, 68(1), 21-37.

Dragańska, E., Szwejkowski, Z., Grabowska, K., Hryniewiecka, D. (2007). Termiczne pory roku w Polsce południowo-wschodniej w latach 1971-2000. Zeszyty Problemowe Postępu Nauk Rolniczych, 519, 57-65.

Fiala, D., Havenith, G., Bröde, P., Kampmann, B., Jendritzky, G. (2012). UTCI Fiala multi-node model of human heat transfer and temperature regulation. International Journal of Biometeorology, 56, 429-441. https://doi.org/10.1007/s00484-011-0424-7

Franków, K. (2008). Termiczne pory roku na Pomorzu Zachodnim w stacji geoekologicznej zintegrowanego monitoringu środowiska przyrodniczego w Storkowie w latach 1987-2007. Badania Fizjograficzne Nad Polska Zachodnia Seria A - Geografia Fizyczna, 59, 77-88.

Gumiński, R. (1948). Próba wydzielenia dzielnic rolniczo-klimatycznych w Polsce. Przeglad Meteorologiczny i Hydrologiczny, 1(1), 7-20.

IPCC. (2014). Climate Change 2014: Synthesis Report. Contribution of Working Groups I, II and III to the Fifth Assessment Report of the Intergovernmental Panel on Climate Change. Core Writing Team, R.K, Pachauri, L.A, Meyer (Eds.). Geneva: IPCC.

Kossowska-Cezak, U. (2005). Zmiany termicznych pór roku w Warszawie w okresie 1933-2004. Przeglad Geofizyczny, 3-4, 265-277.

Koźmiński, Cz. (1983). Agroklimat województwa szczecińskiego. Szczecin: Szczecińskie Towarzystwo Naukowe.

Koźmiński, Cz., Michalska, B. (2004). Atlas zasobów i zagrożeń klimatycznych Pomorza. Szczecin: Wydawnictwo Zapol.

Koźmiński, Cz., Michalska, B. (2019). Assessment of bioclimatic conditions for recreation and tourism in the Polish Baltic coastal zone using the UTCI index. Przeglad Geograficzny, 91(2), 113-126. https://doi.org/10.7163/PrzG.2019.2.7

Koźmiński, Cz., Michalska, B., Czarnecka, M. (2012). Klimat województwa zachodniopomorskiego. Szczecin: Wydawnictwo Zapol.

Kożuchowski, K. (2004). The scale and tendencies of the contemporary changes in air temperature in Poland. In K. Kożuchowski (Ed.), Skala, uwarunkowania i perspektywy współczesnych zmian klimatycznych w Polsce (pp. 25-46). Łódź: Wydawnictwo Biblioteka, UŁ.

Kożuchowski, K, Degirmendžić, J. (2005). Contemporary changes of climate in Poland: trends and variation in thermal and solar conditions related to plant vegetation. Polish Journal of Ecology, 53, 283-297.

Kożuchowski, K., Degirmedzić, J., Fortuniak, K. (1999). Tendencje zmian sezonowych aspektów klimatu w Polsce. In Zmiany i zmienność klimatu Polski. Ogólnopolska Konferencja Naukowa, Łódź, 4-6 listopada 1999 (pp. 107-122).

Kożuchowski, K., Żmudzka, E. (2001). Ocieplenie w Polsce: skala i rozkład sezonowy zmian temperatury powietrza w drugiej połowie XX wieku. Przeglad Geofizyczny, 46(1-2), 81-90.

Krzyżewska, A., Wereski, S., Dobek, M. (2020). Summer UTCl variability in Poland in twenty-first century. International Journal of Biometeorology, Special Issue: UTCI - 10 years of applications, 1-17. https://doi.org/10.1007/s00484-020-01965-2 
Kuchcik, M. (2006). Weather in Poland and mortality: today and in the light of climate change forecasts. Balneologia Polska, 4, 239.

Kuchcik, M. (2017). Warunki termiczne w Polsce na przełomie XX i XXI wieku i ich wpływ na umieralność. Prace Geograficzne, 263, Warsaw: IGIPZ PAN.

Kuchcik, M. (2020). Mortality and thermal environment (UTCI) in Poland-long-term, multi-city study. International Journal of Biometeorology. https://doi.org/10.1007/s00484-020-01995-w

Kuchcik, M., Błażejczyk, K., Halaś, A. (2021). Long-term changes in hazardous heat and cold stress in humans: multi-city study in Poland. International Journal of Biometeorology. https://doi.org/10.1007/s00484-020-02069-7

Kuchcik, M., Błażejczyk, K., Szmyd, J., Milewski, P., Błażejczyk, A., Baranowski, J. (2013). Potencjał leczniczy klimatu Polski. Warsaw: Wydawnictwo Akademickie SEDNO.

Lorenc, H. (2000). Studia nad 220-letniq serią temperatury w Warszawie oraz ocena jej wiekowych tendencji. Materiały Badawcze IMGW, seria. Meteorologia 31, 7-37.

Majewski, G., Przewoźniczuk, W. (2014). Thermal seasons in Warsaw during the period 1961-2013. Miscellanea Geographica - Regional Studies on Development, 18(4), 41-46. https://doi.org/10.2478/mgrsd-2014-0025

Mąkosza, A. (2013). Bioclimatic conditions of the Lubuskie Voivodeship. Geographia Polnica, 86(1), 37-46. https://doi.org/10.7163/GPol.2013.5

Michalska, B. (2009). Variability of air temperature in North western Poland. In Z. Szwejkowski (Ed.), Environmental aspects of climate change (pp. 89-107). Olsztyn: Uniwersytet Warmińsko-Mazurski.

Michalska, B. (2011). Tendencje zmian temperatury powietrza w Polsce. Prace i Studia Geograficzne, 47, 67-75.

Nidzgorska-Lencewicz, J. (2015). Variability of human-biometeorological conditions in Gdańsk. Polish Journal of Environmental Studies, 24(1), 215-226. https://doi.org/10.15244/pjoes/26116

Nidzgorska-Lencewicz, J., Mąkosza, A. (2008). Zmienność występowania termicznych pór roku na Nizinie Szczecińskiej. Folia Universitatis Agriculturae Stetinensis, 26 (7), 77-86.

Nidzgorska-Lencewicz, J., Mąkosza, A. (2013). Assessment of bioclimatic conditions within the area of Szczecin agglomeration. Meteorologische Zeitschrift, 22(5), 1-14. https://doi.org/10.1127/0941-2948/2013/0451

Nowosad, A., Rodzik, B., Wereski, S., Dobek, M. (2013). The UTCI Index in Lesko and Lublin and its circulation determinants. Geographia Polonica, 86(1), 29-36. https://doi.org/10.7163/GPol.2013.4

Olechnowicz-Bobrowska, B., Wojkowski, J. (2006). Okresy termiczne w południowej części Wyżyny Krakowsko-Częstochowskiej (1991-2000). In J. Trepińska, Z. Olecki (Eds.), Klimatyczne aspekty środowiska geograficznego (pp. 51-61). Kraków: IGiGP UJ.

Piotrowicz, K. (2000a). Sposoby wydzielania pór roku. Przegląd Geofizyczny, 47(3-4), 261-278.

Piotrowicz, K. (2000b). Zróżnicowanie termicznych pór roku w Krakowie. Prace Geograficzne, 105, 111-124, Kraków: Instytut Geografii UJ.

Piotrowicz, K. (2002). Metody wyznaczania dat początku i końca termicznych zim na przykładzie krakowskiej serii pomiarów temperatury powietrza. Przeglad Geofizyczny, (1-2), 81-92.

Półrolniczak, M., Szyga-Pluta, K., Kolendowicz, L. (2016). Bioklimat wybranych miast pasa pobrzeży południowobałtyckich na podstawie uniwersalnego wskaźnika obciążenia cieplnego. Acta Geographica Lodziensia, 104, 147-161.

Rozbicka, K., Rozbicki, T. (2018). Variability of UTCl index in South Warsaw depending on atmospheric circulation. Theoretical and Applied Climatology, 133(1-2), 511-520.

https://doi.org/10.1007/s00704-017-2201-y

Szyga-Pluta, K. (2011). Zmienność termicznych pór roku w Poznaniu. Badania Fizjograficzne R 2- Seria A - Geografia Fizyczna (A62),181-195. https://hdl.handle.net/10593/9800 
Tomczyk, A.M., Owczarek, M. (2020). Occurrence of strong and very strong heat stress in Poland and its circulation conditions. Theoretical and Applied Climatology, 139, 893-905. https://doi.org/10.1007/s00704-019-02998-3

Trepińska, J. (2001). Fluktuacje termiczne w Europie od małej epoki lodowej do końca XX wieku. Prace iStudia Geograficzne, 29, 73-76.

Urban, A., Kyselý, J. (2014). Comparison of UTCI with other thermal indices in the assessment of heat and cold effects on cardiovascular mortality in the Czech Republic. International Journal of Environmental Research and Public Health, 11(1), 952-967. https://doi.org/10.3390/ijerph110100952

Wereski, S., Krzyżewska, A., Dobek, M. (2020). Winter UTCI variability in Poland in 21st century. Miscellanea Geographica, 24(3), 128-137. https://doi.org/10.2478/mgrsd-2020-0021

Woś, A. (2006). Termiczne pory roku w Poznaniu w drugiej połowie XX wieku. In J. Trepińska, Z. Olecki (Eds.), Klimatyczne aspekty środowiska geograficznego (pp. 117-126). Kraków: IGiGP UJ.

Żmudzka, E. (2004). Tendencje zmian a zróżnicowanie przestrzenne elementów klimatu w Polsce w drugiej połowie XX wieku. In Z. Michalczyk (Ed.), Badania geograficzne w poznawaniu środowiska (pp. 452-458). Lublin: Polskie Towarzystwo Geograficzne, UMCS.

Żmudzka, E. (2010). Changes in thermal conditions in the high mountain areas and contemporary warming in the central Europe. Miscellanea Geographica, 14, 59-70.

https://doi.org/10.2478/mgrsd-2010-0006 